\title{
CONTRIBUTIONS TO THE BRYOPHYTE FLORA OF THE PAIKO, TZENA AND PINOVO MTS IN GREECE
}

\author{
Beáta PAPP ${ }^{1 *}$ and Eudoxia TsAKIRI ${ }^{2}$ \\ ${ }^{1}$ Department of Botany, Hungarian Natural History Museum, \\ H-1431 Budapest, Pf. 137, Hungary; *papp.beata@nhmus.hu \\ ${ }^{2}$ Laboratory of Systematic Botany and Phytogeography, Department of Botany, School of Biology, \\ Aristotle University of Thessaloniki, Thessaloniki 541 24, Greece
}

Papp, B. \& Tzakiri, E. (2017): Contributions to the bryophyte flora of the Paiko, Tzena and Pinovo Mts in Greece. - Studia bot. hung. 48(1): 33-49.

\begin{abstract}
: 196 bryophyte taxa (30 liverworts and 166 mosses) were recorded in the investigated mountain areas. Five species (Myurella sibirica, Plagiobryum zierii, Poblia andalusica, Pseudoleskeella rupestris, Tortella fragilis) are reported for the first time in Greece. Three species (Seligeria pusilla, Syntrichia subpapillosissima, Taxiphyllum wissgrillii) are reported for the first time from the Greek mainland. For two species (Orthotrichum alpestre, Rhabdoweisia fugax) the second records from Greece are reported. Six species (Myurella sibirica, Neckera menziesii, Orthotrichum shawii, Pseudoleskeella rupestris, Plagiothecium platyphyllum, Schistidium papillosum) are on the candidate list of the new Red data book of European bryophytes.
\end{abstract}

Key words: liverworts, mosses, new and interesting national records, European red list candidates

\section{INTRODUCTION}

The bryophyte flora of Greece is slowly being enriched with reports on new taxa. In the recent checklist and country red list status of European bryophytes (HodgetTs 2015) the majority of the reported taxa in Greece were included. Afterwards, the latest published reports give information mainly on the bryophyte flora of the Aegean Islands (BLockeel 2016, BLOCKeEL and NeUw Koop 2016, DÜLL 2014, KIEBACHER and LÜTH 2016).

Most of the work published so far for Greece are providing data on the bryoflora of the Aegean Islands, Crete, and the southern part of the country, which are the most popular touristic parts and there are much fewer records from the mainland of Greece, especially from Northern Greece. For the Macedonia region of Northern Greece, records have started accumulating only the last years, providing many new taxa for the country. $\mathrm{A} \mathrm{PhD}$ Thesis covering the aquatic system 
of the Aliakmon River was one of the first reports covering a significant area of this region (TSAKIRI 2009), followed by a number of reports mainly attributed to the collaboration of the Hungarian Natural History Museum of Budapest (Hungary) and the Laboratory of Systematic Botany and Phytogeography, Aristotle University of Thessaloniki (Greece) (TsAKIRI et al. 2006, PAPP and TSAKIRI 2011, PAPP et al. 2011a).

Some years before, during study trips in 2005 and 2010, Mt Voras was visited and number of interesting new bryophyte records have been reported (TSAKIRI et al. 2006, PApP et al. 2011a). As the Pinovo and Tzena Mts are situated next to Mt Voras towards East, it was decided to visit these areas, expanding the study also to the Mt Paiko area due to its vicinity and study the hepatics and mosses of the area. From the Pinovo and Tzena Mts there are no previous bryophyte records available, though for the Mt Paiko area one report exists providing data on bryophytes from a small area, the Skra-Koupa waterfalls (Megalo Rema stream) and its tuff formations (PAPP and TSAKIRI 2011).

As one of the members of our expedition in 2010 in Mt Voras was Peter Erzberger, we are glad to publish this paper in a volume in honour of his 70th birthday, as a continuation and extension of our joint bryological contribution to the area.

\section{MATERIAL AND METHODS}

\section{Study area}

The Pinovo (2154 m), Tzena (2182 m), and Paiko (1650 m) Mts are situated in central Northern Greece (Central Macedonia Administrative Region). The Pinovo and Tzena Mts stretch along the north-central border of Greece and together with the adjacent Mt Voras range, which is on their west side, form a natural mountain border with the Republic of Macedonia. Mt Paiko forms their continuum on an E-S direction of Mt Tzena.

Geologically the study area belongs to the "Paiko Zone" with the Pinovo and Tzena Mts. Substrates comprised mainly of schist and limestone, though Mt Paiko is formed mainly of limestone, ophiolites and on the Paiko's southeastern part mainly of sedimentary rocks (DAFIs et al. 1996, 1985).

The climate is characterised as sub-Mediterranean with short, dry, and warm summer, though with severe winter weather reported in higher elevations (Korakis 2003, Athanasiadis and Drosos 1990).

Extensive, densely forested areas cover around $50 \%$ of the study area. A variety of habitats is reported, such as Juniperus communis formations on calcareous heaths or grasslands; Quercus frainetto forests; acidophilous beech for- 
ests (Luzulo-Fagetum); nitrophilous beech forests (Asperulo-Fagetum); calcareous beech forests (Cephalanthero-Fagion); Platanion orientalis along streams; acidophilous spruce forests (Vaccinio-Piceetea), etc. From the Pinovo and Tzena Mts beech forests are also reported with Ilex aquifolium and Taxus baccata (IliciFagion), Hellenic beech forests with Abies borisii-regis and at higher altitudes steep slopes with alpine and subalpine heaths. For Mt Paiko extensive Castanea sativa areas, forests of Pinus nigra subsp. pallasiana and Taxus baccata forests are additionally reported (DAFIs et al. 1996).

The Pinovo and Tzena Mts form the "Ori Tzena" (GR1240002) and Mt Paiko the "Oros Paiko" (GR 1240003) "Special Areas of Conservation" in the framework of the Natura 2000 project, covering together more than 47,800 hectares (DAfis et al. 1996). The Pinovo and Tzena Mts form mountain peaks with steep slopes, though Mt Paiko, with its significantly lower altitude, has a milder relief. The area which was mostly affected by human activities is Mt Paiko with forests being heavily exploited and intensive grazing that led to the degradation of natural environment; only the last decades there are signs that recovery of natural vegetation has started.

\section{METHODS}

The collecting trip was made in August 2014. The investigated area is shown in Figure 1. Main habitat types, such as stream valleys, forests, and grasslands were investigated. Bryophytes were collected from different substrates (soil, exposed and shady rocks, tree bark, decaying wood). The specimens have been shared between the participating parties and are preserved in the Herbarium of the Hungarian Natural History Museum, Budapest (BP), and the bryophyte collection of Dr E. TSAKIRI (Laboratory of Systematic Botany and Phytogeography, School of Biology, Aristotle University, Thessaloniki, Greece).

Nomenclature follows GROLLE and LONG (2000) for liverworts with the exception of Conocephalum salebrosum, which follows SzWEYKOWs Ki et al. (2005), and Hill et al. (2006) for mosses. New floristic results are given mainly according to the recently published "Checklist and country status of European bryophytes" (HodgetTs 2015). In some cases, other earlier and the most recently published works were also used (e.g. Düll 1995, Gallego 2005, Blockeel 2010, 2016, Blockeel and NeuWkoop 2016, Düll 2014, KiebACHER and LÜTh 2016).

\section{Site details}

All sites are located in Central Macedonia (Greece).

1. Between Pinovo and Tzena Mts towards Pefka from Aetohori village, $41.106778^{\circ} \mathrm{N}, 22.1770^{\circ} \mathrm{E}$, $1055 \mathrm{~m}, 21.08 .2014$. 
2. Between Pinovo and Tzena Mts towards Pefka from Aetohori village, $41.117944^{\circ} \mathrm{N}, 22.172806^{\circ}$ E, $1400 \mathrm{~m}, 21.08 .2014$.

3. Between Pinovo and Tzena Mts towards Pefka from Aetohori village, $41.118083^{\circ} \mathrm{N}, 22.165611^{\circ}$ E, $1415 \mathrm{~m}, 21.08 .2014$.

4. Between Pinovo and Tzena Mts towards Pefka from Aetohori village, in Fagetum, $41.117528^{\circ} \mathrm{N}$, $22.167167^{\circ} \mathrm{E}, 1350 \mathrm{~m}, 22.08 .2014$.

5. Between Pinovo and Tzena Mts towards Pefka from Aetohori village, $41.124722^{\circ} \mathrm{N}, 22.169778^{\circ}$ E, $1340 \mathrm{~m}, 22.08 .2014$.

6. Between Pinovo and Tzena Mts, towards Pefka from Aetohori village, $41.105028^{\circ} \mathrm{N}, 22.182611^{\circ}$ E, $860 \mathrm{~m}, 22.08 .2014$.

7. Mt Tzena, $\mathrm{N}$ of Notia village, $41.122583^{\circ} \mathrm{N}, 22.187028^{\circ} \mathrm{E}, 990 \mathrm{~m}, 22.08 .2014$.

8. Mt Tzena, $\mathrm{N}$ of Notia village, $41.129639^{\circ} \mathrm{N}, 22.180556^{\circ} \mathrm{E}, 1000 \mathrm{~m}, 22.08 .2014$.

9. Mt Tzena, $\mathrm{N}$ of Notia village, $41.111667^{\circ} \mathrm{N}, 22.223028^{\circ} \mathrm{E}, 685 \mathrm{~m}, 23.08 .2014$.

10. Mt Tzena, $\mathrm{N}$ of Notia village, $41.130278^{\circ} \mathrm{N}, 22.188306^{\circ} \mathrm{E}, 1280 \mathrm{~m}, 23.08 .2014$.

11. Mt Tzena, $\mathrm{N}$ of Notia village, $41.145972^{\circ} \mathrm{N}, 22.190806^{\circ} \mathrm{E}, 1540 \mathrm{~m}, 23.08 .2014$.

12. Mt Tzena, above Langadia village, $41.129722^{\circ} \mathrm{N}, 22.266944^{\circ} \mathrm{E}, 770 \mathrm{~m}, 25.08 .2014$.

13. Mt Tzena, above Langadia village in a Fagetum, $41.130611^{\circ} \mathrm{N}, 22.251^{\circ} \mathrm{E}, 1090 \mathrm{~m}, 25.08 .2014$.

14. Mt Paiko, between Kastaneri and Livadia, forest road above Vale Orvo, $40.974111^{\circ} \mathrm{N}$, $22.304167^{\circ} \mathrm{E}, 1280 \mathrm{~m}, 24.08 .2014$.

15. Mt Paiko, between Kastaneri and Livadia, forest road above Vale Orvo towards Koufia Petra, $40.967722^{\circ} \mathrm{N}, 22.294083^{\circ} \mathrm{E}, 1390 \mathrm{~m}, 24.08 .2014$.

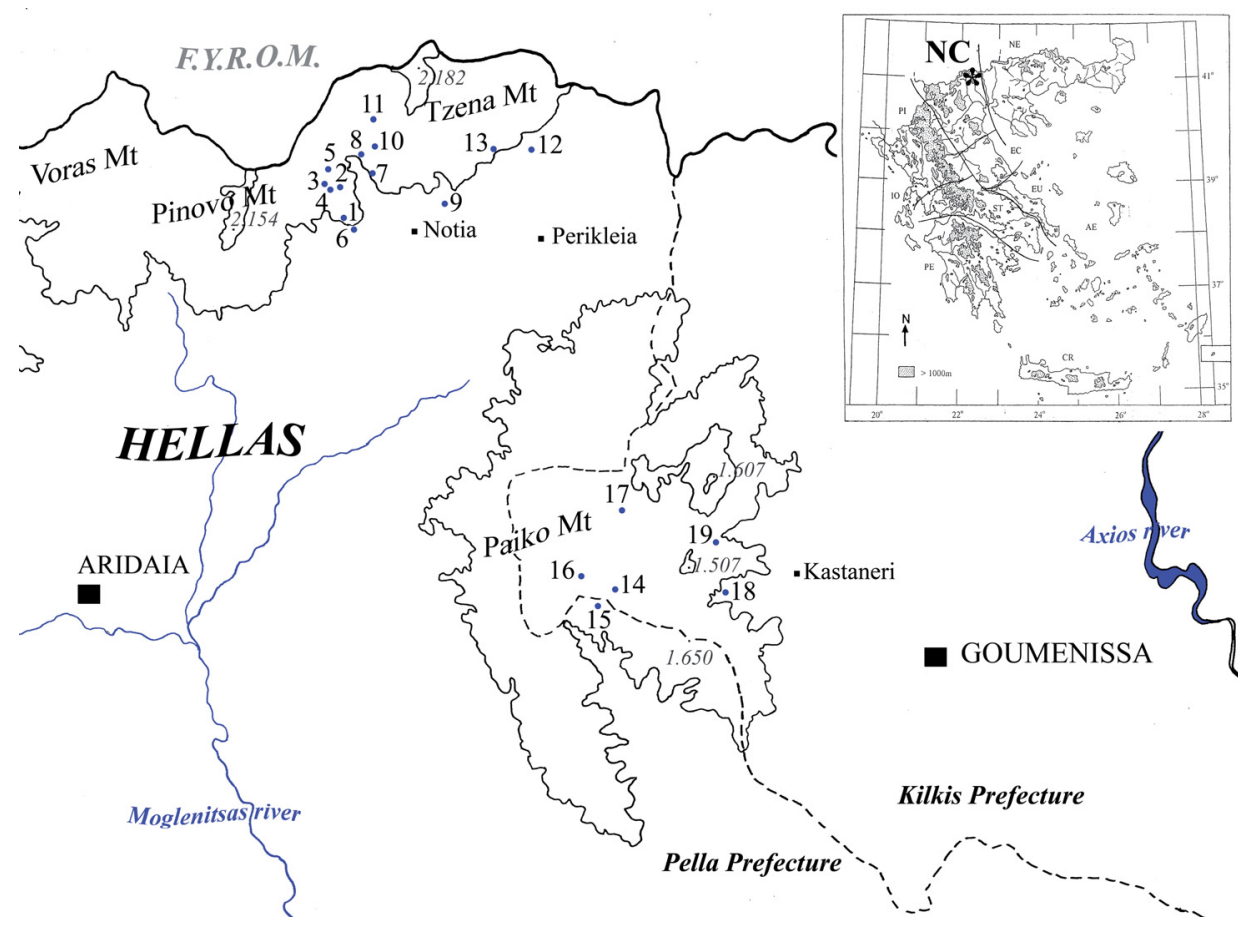

Fig. 1. The study area. 
16. Mt Paiko, between Kastaneri and Livadia, forest road from Vale Orvo towards Gkrop and Mertzana, in a Fagetum, $40.974611^{\circ} \mathrm{N}, 22.287944^{\circ} \mathrm{E}, 1400 \mathrm{~m}, 24.08 .2014$.

17. Mt Paiko, near Livadia, at Mertzana stream, at the roadside, $40.99825^{\circ} \mathrm{N}, 22.297444^{\circ} \mathrm{E}, 1190$ $\mathrm{m}, 24.08 .2014$.

18. Mt Paiko, above Kastaneri village, Castanetum, $40.971528^{\circ} \mathrm{N}, 22.351583^{\circ} \mathrm{E}, 980 \mathrm{~m}, 25.08 .2014$. 19. Mt Paiko, above Kastaneri village, Stravopotamu stream, Pramatari tourist path in a Fagetum, $40.989583^{\circ} \mathrm{N}, 22.346306^{\circ} \mathrm{E}, 1095 \mathrm{~m}, 26.08 .2014$.

\section{RESULTS AND DISCUSSION}

196 bryophyte taxa ( 30 liverworts and 166 mosses) were recorded in the investigated mountain areas. The complete list of the species can be found in the Appendix.

\section{New and interesting records for Greece}

Myurella sibirica (Müll. Hal.) Reimers is a subarctic, alpine element (DüLL 1985). It is reported for the first time in Greece. In SE Europe it is known only from Slovenia and Bosnia-Herzegovina according to SABOVLJEvić et al. (2008) and has been only recently reported from Montenegro and Serbia (PAPP et al. 2014a). According to the Red data book of European bryophytes (ECCB 1995) it is considered as endangered (E) in Europe. It is on the candidate list of the new Red data book of European bryophytes (HoDGETTS 2015). It is known only from a few countries in Europe; in Austria it is considered as potentially endangered (Grims 1999), and in Slovakia as endangered (EN) (KUBINSKÁ et al. 2001). It lives on shaded limestone rocks, on soil at cliff bases (ECCB 1995). It was collected on a lime containing schistose rock in Mt Tzena above $1500 \mathrm{~m}$ at the edge of a beech forest close to its border with alpine zone. It occurred together with $M$. julacea (Schwägr.) Schimp.

Orthotrichum alpestre Bruch et Schimp. is a subarctic, subalpine (DüLL 1985) epiphyte species. It had one old report in DüLL (1995) from Pindos area by HAUSS KNECHT (1899), which needed verification. Later on, it has been verified for the Pindos area by LARA et al. (2003). It was recently collected in Mt Paiko from decaying Fagus bark. This is the second verified record of the species from Greece.

Plagiobryum zieri (Hedw.) Lindb. is a subarctic, subalpine element (DüLL 1985) living in shaded limestone rock crevices (SMITH 2004). It is reported for the first time in Greece. It was known from almost all SE European countries except Kosovo, the European part of Turkey, and Greece (HodgetTs 2015). It was collected on a lime containing schistose rock in Mt Tzena in a beech forest above $1500 \mathrm{~m}$, close to its border with alpine zone. 
Poblia andalusica (Höhn.) Broth. is a sub-Atlantic, montane element (DüLL 1984) occurring on damp sandy soil and clay (SMITH 2004). It is reported for the first time in Greece. In SE Europe it is known only from Montenegro, Republic of Macedonia, Serbia, and Romania, where it is red-listed as data deficient (DD) (HodgetTs 2015). It was collected from acidic soil in Mt Tzena above $1500 \mathrm{~m}$, at the edge of a beech forest close to its border with alpine zone.

Pseudoleskeella rupestris (Berggr.) Hedenäs et L. Söderstr. is a circumpolar, boreal, montane (SMITH 2004) species previously treated as a variety of P. catenulata. This moss is newly reported for the Balkans, from Montenegro (DRAGIĆEvić et al. 2008), Albania (PAPP et al. 2010), Serbia (PAPP et al. 2014b), Croatia (Alegro et al. 2015), and the Republic of Macedonia (PAPP et al. 2016a). From the Mediterranean region it is known from Spain, France, and Turkey (Ros et al. 2013). It is reported for the first time in Greece. It is on the candidate list of the new Red data book of European bryophytes (HoDGETTS 2015). It usually occurs on limestone rocks (SMITH 2004). It was collected in Mt Paiko from limestone rock on the bank of a stream in a beech forest.

Rhabdoweisia fugax (Hedw.) Bruch et Schimp. is a boreal, montane species (DüLL 1984) occurring on non-basic rock crevices, cliffs (SMITH 2004). It was reported from the neighbouring Mt Voras as new species for the Greek bryoflora (PAPp et al. 2011a). It was collected between the Pinovo and Tzena Mts, in crevices of exposed acidic rock situated above $1400 \mathrm{~m}$. It is the second record of the species from Greece.

Schistidium confertum (Funck) Bruch et Schimp. is a subboreal, montane species (DülL 1984). It was included with question mark for North Central Greece in DüLL (1995) (Schistidium apocarpum cf. var. confertum). Later it was reported from the Pindos area, Mt Smolikas by BLOCKEEL (2010). It was also collected in the neighbouring Mt Tzena from siliceous rock (PAPP et al. 2011a). However, the occurrence of the species is questionable for Greece in HodGetTs (2015). It was collected again from exposed acidic rocks in the Pinovo and Tzena Mts.

Seligeria pusilla (Hedw.) Bruch et Schimp. is a tiny species of the temperate zone of Europe (DüLL 1984) living in calcareous rock crevices, shaded, humid vertical cliffs (SMITH 2004). Its occurrence is questionable for Greece in Hodgetts (2015), although it was reported by DüLL (1995) from Crete and some old records are also mentioned for the Ionian islands by GREVILLE (1827) and Bottini (1913). It was found in Mt Tzena on lime containing schist and in Mt Paiko on shaded limestone rocks. This is the first record of the species from the mainland of Greece.

Syntrichia subpapillosissima (Bizot et R. B. Pierrot ex W. A. Kramer) M. T. Gallego et J. Guerra is an Atlantic, Mediterranean element according to DÜLL (1984) and occurs on soil and acidic rocks (GALLEgo 2006). It was reported 
from Crete by Gallego (2005). In Hodgetts (2015) there is no record for SE Europe. However, it has been recently reported from Croatia (PAPP et al. 2013a) and from the Republic of Macedonia (PAPP et al. 2016a). It was found on exposed acidic rocks in Mt Tzena. This is its first record from the mainland of Greece.

Taxiphyllum wissgrillii (Garov.) Wijk et Margad. is a sub-Atlantic species (DüLL 1985) growing on shaded limestone rocks (SMITH 2004). According to HodgetTs (2015) it was known from almost all SE European countries, except Albania, Kosovo, the Republic of Macedonia, and Greece. However, in DüLL (1995) it was reported from Crete. Later on it has been reported from the Republic of Macedonia (PAPP et al. 2016a). It is red-listed in Bulgaria (VU) (HodgetTs 2015). It was collected in Mt Paiko from shaded limestone rocks in a deep valley covered with beech forest. This is the first record of the species from the mainland of Greece.

Tortella fragilis (Hook. et Wilson) Limpr. is a subarctic, subalpine species (DüLL 1984) living on basic rocks (SMITH 2004). It is reported for the first time in Greece. It has been reported from several SE European countries, e.g. BosniaHerzegovina, Bulgaria, Montenegro, Romania, Serbia, Slovenia (HodgetTs 2015) and recently from Croatia (PAPP et al. 2013a) and the Republic of Macedonia (PAPP et al. 2016a). It is red-listed in Bulgaria (VU) (HodgetTs 2015). It was collected from exposed acidic rocks in the alpine zone of Mt Tzena above $1500 \mathrm{~m}$.

Species of European conservation interest - candidates of the new Red data book of European bryophytes

Myurella sibirica (Müll. Hal.) Reimers and Pseudoleskeella rupestris (Berggr.) Hedenäs et L. Söderstr. have already been mentioned above as new species for the Greek bryoflora and candidates of the new Red data book of European bryophytes (HodGETTs 2015). Myurella sibirica is also included in the Red data book of European bryophytes in the endangered (E) category (ECCB 1995).

Neckera menziesii Drumm. is a sub-Mediterranean, sub-Atlantic, montane element (DÜLL 1985) occurring on shaded siliceous or calcareous rocks (AHRENS 2001, Cortini Pedrotti 2006). It is red-listed in many Central European countries (HodgetTs 2015), but probably it is not so rare in SE Europe evidenced even by our many recent collections from Serbia: Golija Biosphere Reserve, Suva Mts, Pešter plateau (PAPP and Erzberger 2005, 2009, PAPP et al. 2014c), from Montenegro: Lovćen, Durmitor, Bjelasica Mts (PAPP and Erzberger 2007a, 2010, PAPP et al. 2013b), from Bulgaria, Strandzha Mts (PAPP et al. 2011b), from Albania (PAPP et al. 2010), from the Republic of Macedonia, Mavrovo Mts (PAPP et al. 2016b). It was also reported from the neighbouring Mt Voras in Greece (PAPp et al. 2011a). 
Orthotrichum shawii Wilson is a southern sub-Atlantic epiphyte species (SMith 2004). It has been recently separated from its close relative, O. striatum (MAZIMPAKA et al. 2000). In SE Europe it is known only from Albania and Greece (HodgetTs 2015) and it has recently been reported from the Republic of Macedonia (PAPP et al. 2016a).

Plagiothecium platyphyllum Mönk. is a sub-Atlantic species (DÜLL 1985) occurring on humid acidic soil and rocks (SMITH 2004). It is red-listed in many European countries and even in SE Europe it is vulnerable (VU) in Bulgaria and near threatened (NT) in Romania (HodgetTs 2015). However, in the Balkans several existing populations are known on the base of our recent collections in Croatia: Gorski kotar, Plitvice lakes, Žumberačko Mts (PAPP et. al. 2013c, AlEgRo et al. 2014, 2015), in Montenegro: Durmitor, Bjelasica Mts (PAPP and Erzberger 2010, PAPP et al. 2013b), in Serbia: Golija Biosphere Reserve (PAPP and ERzBERGER 2005), in the Republic of Macedonia: Pelister Mts (PAPP and Erzberger 2012). It was also reported from the neighbouring Voras Mts in Greece (PAPP et al. 2011a).

Schistidium papillosum Culm. is a circumpolar, boreo-arctic, montane species (SMITH 2004) living mostly on exposed or half-shaded siliceous rocks (NEBEL and Holz 2000). As it has recently been reported from many countries in SE Europe it is in the data-deficient (DD) category in most national red lists (HoDGETTs 2015). According to our recent collections it does not seem to be rare in the Balkans in the higher mountain areas on exposed acidic rocks, e.g. Stara Planina Mts, Stolovi Mt at Ibar gorge and mountains around Vlasina lake in Serbia (PAPP and ERZBERGER 2007b, PAPP et al. 2012, 2016c), Bjelasica Mts in Montenegro (PAPP et al. 2013b), and some Albanian collections (Papp, unpublished).

\section{CONCLUSIONS}

According to HodgetTs (2015) and the current paper the bryophyte flora of Greece consists of 732 taxa (158 liverworts and 574 mosses). The number of known taxa from Greece is higher than in the neighbouring countries, e.g. Republic of Macedonia with 546 or Albania with 466 taxa, but lower than in Bulgaria, where the bryoflora counts 807 taxa. It can be concluded that the Greek bryoflora is not understudied, but still every field expedition can add new records to the bryophyte checklist. Especially in the northern part of the country several, bryologically still unexplored, interesting areas can be found.

Acknowledgements - The study trip was financially supported by EPPERAA-Ministry of Environment \& Energy, Project: "Monitoring and assessment of the conservation status of Flora species of European Community interest in Greece". 
Összefoglaló: 196 mohát (30 májmohát és 166 lombosmohát) találtunk a vizsgált észak-görögországi hegyekben. Öt fajt (Myurella sibirica, Plagiobryum zierii, Pohlia andalusica, Pseudoleskeella rupestris, Tortella fragilis) elöször sikerült kimutatnunk Görögország területéről. Három fajnak (Seligeria pusilla, Syntrichia subpapillosissima, Taxiphyllum wissgrillii) az első adatát közöljük a görög félszigetről. Két fajnak (Orthotrichum alpestre, Rhabdoweisia fugax) ez a második adata az országban. Hat faj (Myurella sibirica, Neckera menziesii, Orthotrichum shawii, Pseudoleskeella rupestris, Plagiothecium platyphyllum, Schistidium papillosum) természetvédelmi szempontból is érdekes, mivel szerepelnek a potenciális új Európai Moha Vörös Listán.

Görögország mohaflórája így jelenleg 732 fajt számlál, ami több mint a szomszédos Macedóniában (546) vagy Albániában (466) regisztrált fajok száma, de kevesebb, mint a Bulgáriában található fajok száma (807). Görögország mohaflórája eléggé feltártnak mondható, de szinte még minden expedíció új fajokat ad az ország mohaflórájához. Főleg az ország északi részén található hegyvidékek kevésbé kutatottak, így az ide irányuló terepkutatásoktól további új adatokat remélhetünk.

\section{REFERENCES}

Ahrens, M. (2001): Neckeraceae, Neckermoose. - In: Nebel, M. and Philippi, G. (eds): Die Moose Baden-Württembergs, Band 2. Ulmer, Stuttgart, pp. 226-237.

Alegro, A., PAPP, B., SzURdoki, E., ŠEgota, V., ŠAPIĆ, I. and Vukelić,J. (2014): Contribution to the bryophyte flora of Croatia III. National Park Plitvička jezera and some adjacent areas. - Studia bot. hung. 45: 49-65. http://dx.doi.org/10.17110/studbot.2014.45.49

Alegro, A., ŠEgota, V. and PAPp, B. (2015): A contribution to the bryophyte flora of Croatia IV. Žumberačka gora Mts. - Studia bot. hung. 46(1): 5-24. http://dx.doi.org/10.17110/StudBot.2015.46.1.5

Athanasiadis, N. and Drosos, E. (1990): Flora and vegetation of Paiko Mt. - Scient. Ann. Department of Forestry \& Natural Environment, Aristotle University of Thessaloniki 33: 1-148.

BlockeEL, T. L. (2010): The bryophytes of Greece: new records and observations, 2. - Beih. Nova Hedwigia 138: 129-146.

Blockeel, T. L. and Neuwkoop A. W. (2016): The bryophyte flora of Lesbos, Greece. - Herzogia 29(1): $1-34$.

Blockeel, T. L. (2016): The mosses Aschisma carniolicum, Campylostelium strictum and Timmiella flexiseta on the Eastern Aegean Islands, new to Greece, and a second locality for Syntrichia latifolia. - Herzogia 29(1): 52-58.

Bottini, A. (1913): Sulla briologia di Corfú. - Webbia 4: 241-248.

Cortini Pedrotti, C. (2006): Flora dei Muschi d'Italia. Bryopsida (II parte). - Antonio Delfino Editore medicina-scienzia, Roma, Milano, pp. 819-1235.

Dafis, S., Papastergiadou, E., Georghiou, K., Babalonas, D., Georgiadis, T., Papageorgiou, M., Lazaridou, Th. and Tsiaoussi, V. (1996): Directive 92/43/EEC. The Greek 'Habitat' Project NATURA 2000: An overview. Life Contract B4-3200/94/756, Commission of the European Communities DG XI. - The Goulandris Natural History Museum, Greek Biotope/Wetland Centre, Kifissa, $893 \mathrm{pp}$.

DüLL, R. (1984): Distribution of the European and Macaronesian mosses (Bryophytina) I. - Bryol. Beitr. 4: 1-109.

DüLL, R. (1985): Distribution of the European and Macaronesian mosses (Bryophytina) II. Bryol. Beitr. 5: 110-232.

DüLL, R. (1995): Bryophytes of Greece. - Bryol. Beitr. 10: 1-229.

DüLL, R. (2014): A survey of the bryophytes known from the Aegean Islands. - Weissdorn-Verlag, Jena, 185 pp. 
ECCB (1995): Red data book of European bryophytes. - European Committee for Conservation of Bryophytes, Trondheim, $291 \mathrm{pp}$.

Gallego, M. T. (2005): A taxonomic study of the genus Syntrichia Brid. (Pottiaceae, Musci) in the Mediterranean region and Macaronesia. - J. Hattori Bot. Lab. 98: 47-122.

Gallego, M. T. (2006): Syntrichia. - In: Guerra, J., Cano, M. J. and Ros, R. M. (eds): Flora Briofitica Iberica. Pottiales, Encalyptales. Vol. III. Universidad de Murcia, Sociedad Española de Briología, Murcia, pp. 120-143.

Greville, R. K. (1827): Some accounts of a collection of cryptogamic plants from the Ionian islands. - Trans. Linn. Soc. London 15: 335-348.

Grims, F. (1999): Rote Liste gefährdeter Laubmoose (Musci) Österreichs. - In: NiKLfELd, H. (ed.): Rote Listen gefährdeter Pflanzen Österreichs. Grüne Reihe des Bundesministeriums für Umwelt, Jugend und Familie, Wien, pp. 157-171.

Grolle, R. and LoNG, D. G. (2000): An annotated check-list of the Hepaticae and Anthocerotae of Europe and Macaronesia. - J. Bryol. 22: 103-140.

http://dx.doi.org/10.1179/jbr.2000.22.2.103

Hauss KNeCht, H. K. (1899): Symbolae ad floram graecam. Aufzählung der im Sommer 1885 in Griechenland gesammelten Pflanzen. - Mitt. thuring. bot. Ver. Neue Folge 13: 18-77.

Hill, M. O., Bell, N., Bruggeman-Nannenga, M. A., Brugués, M., Cano, M. J., Enroth, J., Flatberg, K. I., Frahm, J.-P., Gallego, M. T., Garilleti, R., Guerra, J., Hedenäs, L., Holyoak, D. T., Hyvönen, J., Ignatov, M. S., Lara, F., Mazimpaka, V., Muñoz, J. and SÖDERSTRÖM, L. (2006): An annotated checklist of the mosses of Europe and Macaronesia. - J. Bryol. 28(3): 198-267. http://dx.doi.org/10.1179/174328206X119998

Hodgetts, N. G. (2015): Checklist and country status of European bryophytes - towards a new red list for Europe. - Irish Wildlife Manuals, No. 84. National Parks and Wildlife Service, Department of Arts, Heritage and the Gaeltacht, Ireland, 125 pp.

KIEBACHER, T. and LÜTH, M. (2016): Orthotrichum bistratosum (Schiffn.) J. Guerra. [Greece] In: ElLIs, L. T. (ed.): New national and regional bryophyte records, 49. - J. Bryol. 38(4): 334. http://dx.doi.org/10.1080/03736687.2016.1225777

Kora KIS, G. (2003): Forest vegetation units of Paiko massif and their evaluation from a reforestation aspect. - PhD Thesis, School of Forestry, Faculty of Agriculture, Forestry and Natural Environment, Aristotle University, Thessaloniki, 329 pp.

Kubinská, A., Janovicová, K. and Soltes, R. (2001): Updated checklist of liverworts, hornworts and mosses of Slovakia. - Bryonora 28: 4-10.

lara, F., Blockeel, T. L., Garilleti, R. and Mazimpaka, V. (2003): Some interesting Orthotrichum species from mainland Greece and Evvia. - J. Bryol. 25: 129-134. http://dx.doi.org/10.1179/037366803235001805

Mazimpaka, V., Lara, F., Garilleti, R., Albertos, B. and lo Giudice, R. (2000): Orthotrichum shawii Wilson, a distinct European species. - J. Bryol. 22: 183-192. http://dx.doi.org/10.1179/jbr.2000.22.3.183

Mountrakis, D. (1985): Geology of Greece. - University Studio Press, Thessaloniki, 207 pp.

Nebel, M. and Holz, I. (2000): Grimmiaceae, Kissenmoose. - In: Nebel, M. and Philippi, G. (eds): Die Moose Baden-Württembergs, Band 1. Ulmer, Stuttgart, pp. 377-456.

PApp, B. and Erzberger, P. (2005): The bryophyte flora of Golija-Studenica Biosphere Reserve and some adjacent sites (SW Serbia, Serbia-Montenegro). - Studia bot. hung. 36: 101-116.

PAPp, B. and Erzberger, P. (2007a): Contribution to the bryophyte flora of Montenegro. - Studia bot. hung. 38: 79-94.

PAPp, B. and Erzberger, P. (2007b): Contribution to the bryophyte flora of Western Stara Planina Mts (E. Serbia). - Studia bot. hung. 38: 95-123. 
PAPp, B. and ERzBerger, P. (2009): Contribution to the bryophyte flora of South-Eastern Serbia: Suva Planina Mts and its surroundings. - Studia bot. hung. 40: 125-142.

PAPP, B. and ERZBerger, P. (2010): Contribution to the bryophyte flora of Durmitor National Park, Montenegro. - Nova Hedwigia 138: 145-161.

PAPp, B. and ERzberger, P. (2012): Contribution to the bryophyte flora of the Former Yugoslav Republic of Macedonia (FYROM). - Polish Bot. J. 57(1): 205-221.

PAPP, B. and TsAKIRI, E. (2011): Contribution to the bryophyte flora of the Skra-Koupa waterfalls area (Mt Paiko, Central Macedonia, North Greece). - Studia bot. hung. 42: 41-50.

PAPp, B., ERzberger, P. and MARKA, J. (2010): Contribution to the bryophyte flora of Eastern Albania (Korça and Kolonja Districts). - Studia bot. hung. 41: 61-88.

Papp, B., Erzberger, P. and Tsakiri, E. (2011a): Contribution to the bryophyte flora of Voras (Nidže) Mts (Greece and the Former Yugoslav Republic of Macedonia). - Studia bot. hung. 42: 51-76.

Papp, B., Natcheva, R. and Ganeva, A. (2011b): The bryophyte flora of Northern Mt Strandzha. - Phytol. Balcan. 17(1): 21-32.

Papp, B., SzUrdoki, E., SABovljević, M. (2012): Bryophyte flora of the Vlasina lake and its surrounding (SE Serbia). - Studia bot. bung. 43: 27-45.

PApp, B., Alegro, A., ŠEgota, V., ŠAPIĆ, I. and Vukelić, J. (2013a): Additions to the bryophyte flora of Croatia. - J. Bryol. 35(2): 140-143. http://dx.doi.org/10.1179/1743282013Y.0000000046

Papp, B., Erzberger, P. and Dragićević, S. (2013b): Contribution to the bryophyte flora of Bjelasica Mts (Montenegro). - Polish Bot. J. 58(1): 293-318. http://dx.doi.org/10.2478/pbj-2013-0030

PAPp, B., Alegro, A., ŠEgota, V., ŠAPIĆ, I. and Vukelić, J. (2013c): Contribution to the bryophyte flora of Croatia I. Gorski kotar Region (W Croatia). - Studia bot. hung. 44: 193-211.

Papp, B., Pantović, J., Sabovljević, M. and Szurdoki, E. (2014a): Myurella sibirica (Müll. Hal.) Reimers, a moss species new to Montenegro and Serbia: its range extension towards south-eastern Europe. - Cryptog. Bryol. 35(3): 321-326. http://dx.doi.org/10.7872/cryb.v35.iss3.2014.321

Papp, B., Pantović, J., Sabovljević, M. and Szurdoki, E. (2014b): Interesting and new species for the bryophyte flora of Serbia. - Herzogia 27(1): 221-225. http://dx.doi.org/10.13158/heia.27.1.2014.221

Papp, B., Szurdoki, E., Pantović, J. and Sabovljević, M. (2014c): Contribution to the bryophyte flora of Pešter plateau, Serbia. - Studia bot. hung. 45: 33-47. http://dx.doi.org/10.17110/StudBot.2014.45.33

Papp, B., Pantović, J., Szurdoki, E. and Sabovljević, M. (2016a): New bryophyte records for the Republic of Macedonia. - J. Bryol.38(2): 168-171. http://dx.doi.org/10.1080/03736687.2015.1113628

Papp, B., Szurdoki, E., Pantović, J. and Sabovljević, M. (2016b): Contribution to the bryophyte flora of Mavrovo National Park (Republic of Macedonia). - Studia bot. hung. 47(2): 279-296. http://dx.doi.org/10.17110/StudBot.2016.47.2.279

Papp, B., Szurdoki, E., Pantović, J. and Sabovljević, M. (2016c): An insights into the bryophyte flora of the Ibar gorge and its surroundings (C and SW Serbia). - Acta Bot. Hung. 58(3-4): 411-423. http://dx.doi.org/10.1556/ABot.58.2016.3-4.10

Sabovljević, M., Natcheva, R., Tsakiri, E., Dihoru, G., Dragićević, S., Erda Ğ, A. and PAPP, B. (2008): Check-list of the mosses of SE Europe. - Phytol. Balcan. 14: 207-244.

SMith, A. J. E. (2004): The moss flora of Britain and Ireland - University Press, Cambridge, 739 pp. 
Szweykowski, J., Buczkowska, K. and Odrzykoski, I. J. (2005): Conocephalum salebrosum (Marchantiopsida, Conocephalaceae) - a new Holarctic liverwort species. - Pl. Syst. Evol. 253: 133-158. http://dx.doi.org/10.1007/s00606-005-0301-0

TSAKIRI, E., PAPP, B. and SzURDoKI, E. (2006): New records on the bryophytes of Mt Voras, North Greece. - Studia bot. hung. 37: 145-155.

TSAKIRI, E. (2009): Bryophyte flora of Greece: phytogeographical and ecological study of bryophytes at the aquatic system of the Ano Aliakmonas River (Western Macedonia). - PhD Thesis, School of Biology, Faculty of Sciences, Aristotle University, Thessaloniki, 356 pp. (in Greek with English summary).

(submitted: 20.03.2017, accepted 27.04.2017)

\section{Appendix - Complete list of bryophyte records}

The numerals following the species names refer to the collection sites described above.

\section{Liverworts}

Aneura pinguis (L.) Dumort. - 11: at a rivulet Apometzgeria pubescens (Schrank) Kuwah. - 16: shaded limestone rock Barbilophozia hatcheri (A. Evans) Loeske - 11: exposed acidic rock Cephaloziella divaricata (Sm.) Schiffn. - 3: exposed acidic rock; 11: soil Chiloscyphus pallescens (Ehrh. ex Hoffm.) Dumort. - 19: at the stream Chiloscyphus polyanthus (L.) Corda - 7: at a rivulet Conocephalum conicum (L.) Dumort. - 11: at a rivulet Conocephalum salebrosum Szweykowski, Buczkowska et Odrzykoski -19: at the stream Frullania dilatata (L.) Dumort. - 3, 14: bark of Fagus; 8, 13: acidic rock; 18: bark of Castanea sativa Jungermannia atrovirens Dumort. - 11: at a rivulet

Jungermannia hyalina Lyell - 11, 14: soil

Jungermannia leiantha Grolle - 11: soil

Leiocolea badensis (Gottsche) Jörg. - 11: lime containing schist

Leiocolea collaris (Nees) Schljakov - 11: lime containing schist; 16, 19: shaded limestone rock; 17: limestone rock

Lejeunea cavifolia (Ehrh.) Lindb. - 19: shaded limestone rock

Lophocolea heterophylla (Schrad.) Dumort. - 14: soil

Lophocolea minor Nees - 11: lime containing schist and soil at a rivulet; 14: soil; 19: shaded limestone rock

Lophozia bicrenata (Schmidel ex Hoffm.) Dumort. - 14: soil

Marchantia polymorpha L. subsp. ruderalis Bischl. et Boisselier - 11: at a rivulet

Metzgeria conjugata Lindb. - 19: shaded limestone rock

Metzgeria furcata (L.) Dumort. - 3: bark of Fagus; 4: acidic conglomerate rock; 7: decaying wood; 11: lime containing schist; 16, 19: shaded limestone rock

Pedinophyllum interruptum (Nees) Kaal. - 16, 19: shaded limestone rock

Pellia endiviifolia (Dicks.) Dumort. - 8: at the stream; 11: lime containing schist and soil at a rivulet; 19: at the stream

Plagiochila porelloides (Torrey ex Nees) Lindenb. - 7: soil and at a rivulet; 8: at the stream; 11: lime containing schist; 16, 19: shaded limestone rock 
Porella cordaeana (Huebener) Mohr - 3: shaded acidic rock and bark of Fagus; 4: acidic conglomerate rock; 8: acidic rock; 11: lime containing schist

Porella platyphylla (L.) Pfeiff. -7 : schistose rock

Preissia quadrata (Scop.) Nees - 11: lime containing schist; 17: limestone rock

Radula complanata (L.) Dumort. - 3, 14: bark of Fagus; 7: soil and decaying wood; 11: lime containing schist; 12 : acidic rock

Reboulia hemisphaerica (L.) Raddi - 11: lime containing schist; 16, 19: shaded limestone rock Scapania calcicola (Arnell et J. Perss.) Ingham - 11: soil

\section{Mosses}

Abietinella abietina (Hedw.) M. Fleisch. - 17: limestone rock

Aloina ambigua (Bruch et Schimp.) Limpr. - 6, 9: sandy loess wall

Amphidium mougeotii (Schimp.) Schimp. - 11: lime containing schist; 19: shaded limestone rock Anomodon attenuatus (Hedw.) Huebener - 8: acidic rock; 19: shaded limestone rock and Fagus bark Anomodon longifolius (Schleich. ex Brid.) Hartm. - 19: shaded limestone rock and Fagus bark Anomodon viticulosus (Hedw.) Hook. et Taylor - 8: at the stream; 16, 19: shaded limestone rock Antitrichia curtipendula (Hedw.) Brid. - 4: acidic conglomerate rock; 8: acidic rock Atrichum undulatum (Hedw.) P. Beauv. - 4: soil; 7, 11: at a rivulet

Barbula convoluta Hedw. - 11: soil and lime containing schist

Barbula unguiculata Hedw. - 2: schistose rock; 6: sandy loess wall; 11: soil

Bartramia halleriana Hedw. - 11: lime containing schist; 19: shaded limestone rock

Bartramia ithyphylla Brid. - 4: soil; exposed acidic rock; 19: shaded limestone rock

Bartramia pomiformis Hedw. - 19: shaded limestone rock

Brachytheciastrum velutinum (Hedw.) Ignatov et Huttunen - 1: acidic rock; 4: soil and decaying wood; 7: soil and decaying wood; 11: soil at a rivulet; 13: acidic rock; 14: soil; 16: shaded limestone rock; 19: shaded limestone rock and decaying wood

Brachythecium glareosum (Bruch ex Spruce) Schimp. - 11: lime containing schist and exposed acidic rock; 19: shaded limestone rock

Brachythecium rivulare Schimp. $-7,11$ : at a rivulet; 8, 19: at the stream

Brachythecium rutabulum (Hedw.) Schimp. - 4: acidic conglomerate rock; 8, 18: soil; 16: shaded limestone rock; 19: shaded limestone rock and rock at the stream

Brachythecium tommasinii (Sendtn. ex Boulay) Ignatov et Huttunen - 16, 19: shaded limestone rock

Bryoerythrophyllum recurvirostrum (Hedw.) P. C. Chen - 11: lime containing schist; 12: sandy conglomerate loess wall; 15: exposed limestone rock; 19: shaded limestone rock

Bryum argenteum Hedw. - 6: sandy loess wall; 15: exposed limestone rock

Bryum caespiticium Hedw. - 2: schistose rock; 12: sandy conglomerate loess wall; 15: exposed limestone rock

Bryum capillare Hedw. - 12: sandy conglomerate loess wall; 14: soil

Bryum dichotomum Hedw. - 15: exposed limestone rock

Bryum moravicum Podp. - 4: soil and decaying wood; 14: Fagus bark

Bryum pallens Sw. ex anon. - 11: at a rivulet; 17: limestone rock

Bryum pallescens Schleich. ex Schwägr. - 2: schistose rock; 11: soil

Bryum pseudotriquetrum (Hedw.) P. Gaertn. et al. - 11: at a rivulet

Campyliadelphus chrysophyllus (Brid.) R. S. Chopra - 11: at a rivulet

Campylophyllum calcareum (Crundw. et Nyholm) Hedenäs - 19: shaded limestone rock and decaying wood

Ceratodon purpureus (Hedw.) Brid. - 2: schistose rock; 11: soil and exposed acidic rock 
Cirriphyllum crassinervium (Taylor) Loeske et M. Fleisch. - 4: acidic conglomerate rock; 19: shaded limestone rock

Cratoneuron filicinum (Hedw.) Spruce - 7: at a rivulet; 8: at the stream; 11: lime containing schist Crossidium squamiferum (Viv.) Jur. - 6: sandy loess wall

Ctenidium molluscum (Hedw.) Mitt. - 8: soil; 11: lime containing schist; 16, 19: shaded limestone rock

Dichodontium pellucidum (Hedw.) Schimp. - 19: shaded limestone rock

Dicranella heteromalla (Hedw.) Schimp. - 14: soil

Dicranella varia (Hedw.) Schimp. - 2: schistose rock; 11, 14: soil

Dicranum scoparium Hedw. - 7: schistose rock; 8, 14: soil; 11: lime containing schist; 19: shaded limestone rock

Didymodon acutus (Brid.) K. Saito - 15: exposed limestone rock

Didymodon fallax (Hedw.) R. H. Zander - 2: schistose rock; 14: soil; 17: limestone rock

Didymodon insulanus (De Not.) M. O. Hill - 4: soil; 7: at a rivulet; 16, 19: shaded limestone rock; 18: soil

Didymodon luridus Hornsch. - 6, 9: sandy loess wall; 15: exposed limestone rock

Didymodon rigidulus Hedw. - 6, 9: sandy loess wall; 11: lime containing schist; 16: shaded limestone rock

Didymodon sicculus M. J. Cano, Ros, García-Zamora et J. Guerra - 5: schistose rock

Didymodon sinuosus (Mitt.) Delogne - 12: sandy conglomerate loess wall

Didymodon spadiceus (Mitt.) Limpr. - 11: at a rivulet

Didymodon vinealis (Brid.) R. H. Zander - 12: sandy conglomerate loess wall

Diphyscium foliosum (Hedw.) D. Mohr - 11: soil

Distichium capillaceum (Hedw.) Bruch et Schimp. - 2: schistose rock; 11: lime containing schist; 16: shaded limestone rock

Ditrichum flexicaule (Schwägr.) Hampe - 3: exposed acidic rock; 11: lime containing schist; 15: exposed limestone rock

Ditrichum pusillum (Hedw.) Hampe - 11: soil

Encalypta ciliata Hedw. - 11: lime containing schist

Encalypta streptocarpa Hedw. - 2: schistose rock; 16, 19: shaded limestone rock; 17: limestone rock

Encalypta vulgaris Hedw. - 12: sandy conglomerate loess wall

Eurhynchiastrum pulchellum (Hedw.) Ignatov et Huttunen var. pulchellum - 7: soil

Eurhynchiastrum pulchellum (Hedw.) Ignatov et Huttunen var. diversifolium (Schimp.) Ochyra et Zarnowiec - 11, 14: soil

Eurhynchium angustirete (Broth.) T. J. Kop. - 11: lime containing schist

Fissidens dubius P. Beauv. - 8: at the stream; 11: lime containing schist; 16, 19: shaded limestone rock

Fissidens taxifolius Hedw. - 11: lime containing schist; 14: soil; 19: shaded limestone rock

Fissidens viridulus (Sw. ex Anon.) Wahlenb. - 11, 14: soil

Grimmia laevigata (Brid.) Brid. - 1, 12: acidic rock

Grimmia muehlenbeckii Schimp. - 4: acidic conglomerate rock; 8, 12: acidic rock

Grimmia orbicularis Bruch ex Wilson - 2: schistose rock

Grimmia ovalis (Hedw.) Lindb. - 3, 11: exposed acidic rock; 13: acidic rock

Grimmia pulvinata (Hedw.) Sm. - 1: acidic rock; 2: schistose rock; 3: exposed acidic rock; 6: sandy loess wall; 12: sandy conglomerate loess wall

Grimmia tergestina Tomm. ex Bruch et Schimp. - 3: exposed acidic rock; 15: exposed limestone rock Gymnostomum aeruginosum $\mathrm{Sm}$. - 11: lime containing schist

Gymnostomum calcareum Nees et Hornsch. - 11: at a rivulet

Hedwigia ciliata (Hedw.) P. Beauv. - 8, 10, 13: acidic rock

Herzogiella seligeri (Brid.) Z. Iwats. - 19: decaying wood 
Homalothecium philippeanum (Spruce) Schimp. - 2: schistose rock; 4: acidic conglomerate rock, 10: acidic rock; 19: shaded limestone rock and Fagus bark

Homalothecium sericeum (Hedw.) Schimp. - 1, 12, 13: acidic rock; 3, 4, 14: bark of Fagus; 7: soil and decaying wood; 8: decaying wood; 16, 19: shaded limestone rock

Homomallium incurvatum (Schrad. ex Brid.) Loeske - 19: shaded limestone rock and at the stream Hygroamblystegium tenax (Hedw.) Jenn. -19: at the stream

Hygrohypnum luridum (Hedw.) Jenn. - 8, 19: at the stream; 11: at a rivulet

Hylocomium splendens (Hedw.) Schimp. - 11: soil; 17: limestone rock

Hypnum cupressiforme Hedw. var. cupressiforme - 4: acidic conglomerate rock; 7: soil and schistose rock; 8: decaying wood; 13: acidic rock; 14: soil and Fagus bark; 18: bark of Castanea sativa

Hypnum cupressiforme Hedw. var. lacunosum Brid. - 1: acidic rock; 3: exposed acidic rock

Isothecium alopecuroides (Lam. ex Dubois) Isov. - 4: acidic conglomerate rock and bark of Fagus; 7: schistose rock; 8: acidic rock; 11: lime containing schist; 16: shaded limestone rock; 19: shaded limestone rock and Fagus bark

Leucodon sciuroides (Hedw.) Schwägr. - 3: exposed acidic rock and bark of Fagus; 8: acidic rock and decaying wood; 12: acidic rock and bark of Quercus pubescens; 14: Fagus bark

Mnium marginatum (Dicks.) P. Beauv. - 11: lime containing schist; 16, 19: shaded limestone rock Mnium stellare Hedw. - 7: at a rivulet; 8: at the stream; 11, 14: soil; 16, 19: shaded limestone rock Mnium thomsonii Schimp. - 11: lime containing schist

Myurella julacea (Schwägr.) Schimp. - 11: lime containing schist

Myurella sibirica (Müll. Hal.) Reimers - 11: lime containing schist

Neckera besseri (Lobarz.) Jur. - 19: shaded limestone rock

Neckera complanata (Hedw.) Huebener - 19: shaded limestone rock and Fagus bark

Neckera crispa Hedw. - 19: shaded limestone rock

Neckera menziesii Drumm. - 16: shaded limestone rock; 19: shaded limestone rock and decaying wood

Orthothecium intricatum (Hartm.) Schimp. - 11: lime containing schist

Orthotrichum affine Schrad. ex Brid. - 1: acidic rock and bark of Ostrya carpinifolia; 12: bark of Quercus pubescens; 18: bark of Castanea sativa

Orthotrichum alpestre Bruch et Schimp. - 19: decaying wood

Orthotrichum anomalum Hedw. - 12: limestone rock

Orthotrichum cupulatum Hoffm. ex Brid. - 11: exposed acidic rock; 19: shaded limestone rock

Orthotrichum lyellii Hook. et Taylor - 4, 14: bark of Fagus; 12: bark of Quercus pubescens; 18: bark of Castanea sativa

Orthotrichum pallens Bruch ex Brid. - 14: Fagus bark; 18: bark of Castanea sativa

Orthotrichum pumilum Sw. ex anon. - 12: bark of Quercus pubescens

Orthotrichum rupestre Schleich. ex Schwägr. - 4: acidic conglomerate rock; 7: schistose rock; 8, 12: acidic rock

Orthotrichum shawii Wilson - 1: bark of Ostrya carpinifolia

Orthotrichum speciosum Nees - 18: bark of Castanea sativa

Orthotrichum stramineum Hornsch. ex Brid. - 14: Fagus bark; 18: bark of Castanea sativa

Orthotrichum striatum Hedw. - 1: acidic rock and bark of Ostrya carpinifolia; 3, 14: bark of Fagus; 18: bark of Castanea sativa

Oxyrrhynchium hians (Hedw.) Loeske - 7: at a rivulet; 11: lime containing schist

Oxyrrhynchium schleicheri (R. Hedw.) Röll - 7: soil; 16, 19: shaded limestone rock

Palustriella commutata (Hedw.) Ochyra - 11: at a rivulet

Philonotis fontana (Hedw.) Brid. - 11: at a rivulet

Philonotis seriata Mitt. - 11: at a rivulet

Plagiobryum zieri (Hedw.) Lindb. - 11: lime containing schist 
Plagiomnium cuspidatum (Hedw.) T. J. Kop. -7 : at a rivulet

Plagiomnium rostratum (Schrad.) T. J. Kop. - 16, 19: shaded limestone rock

Plagiomnium undulatum (Hedw.) T. J. Kop. - 7: at a rivulet; 19: at the stream

Plagiopus oederianus (Sw.) H. A. Crum et L. E. Anderson - 11: lime containing schist; 16, 19: shaded limestone rock

Plagiothecium cavifolium (Brid.) Z. Iwats. - 4: soil and acidic conglomerate rock; 7: at a rivulet; 8: at the stream; 11: lime containing schist

Plagiothecium denticulatum (Hedw.) Schimp. - 14: Fagus bark

Plagiothecium platyphyllum Mönk. - 7: soil

Plasteurhynchium striatulum (Spruce) M. Fleisch. - 16, 19: shaded limestone rock

Platydictya jungermannoides (Brid.) H. A. Crum - 16, 19: shaded limestone rock

Platybypnidium riparioides (Hedw.) Dixon $-8,19$ : at the stream

Pogonatum aloides (Hedw.) P. Beauv. - 4, 11, 14: soil

Poblia andalusica (Höhn.) Broth. - 11: soil

Poblia cruda (Hedw.) Lindb. - 2: schistose rock; 4: soil; 17: limestone rock; 19: shaded limestone rock

Poblia melanodon (Brid.) A. J. Shaw - 7: at a rivulet; 14: soil

Poblia wablenbergii (F. Weber et D. Mohr) A. L. Andrews - 11: soil at a rivulet; 14: soil; 17: limestone rock

Polytrichastrum alpinum (Hedw.) G. L. Sm. - 2: schistose rock; 11: soil

Polytrichastrum formosum (Hedw.) G. L. Sm. - 8, 14: soil

Polytrichum juniperinum Hedw. - 2: schistose rock; 11: soil

Pseudocrossidium revolutum (Brid.) R. H. Zander - 15: exposed limestone rock

Pseudoleskea incurvata (Hedw.) Loeske - 11: lime containing schist

Pseudoleskea saviana (De Not.) Latzel - 3: bark of Fagus; 4: acidic conglomerate rock; 11: decaying wood; 16: shaded limestone rock

Pseudoleskeella catenulata (Brid. ex Schrad.) Kindb. - 11: exposed acidic rock

Pseudoleskeella nervosa (Brid.) Nyholm - 3: bark of Fagus; 4: decaying wood; 11: lime containing schist and at a rivulet; 13: acidic rock; 19: shaded limestone rock

Pseudoleskeella rupestris (Berggr.) Hedenäs et L. Söderstr. -19: at the stream

Pseudoscleropodium purum (Hedw.) M. Fleisch. - 17: limestone rock; 18: soil

Pterigynandrum filiforme Hedw. - 3, 14: bark of Fagus; 4: acidic conglomerate rock; 7: soil and schistose rock and decaying wood; 11: lime containing schist; 13: acidic rock; 18: bark of Castanea sativa; 19: decaying wood

Pterygoneurum ovatum (Hedw.) Dixon - 15: exposed limestone rock

Racomitrium canescens (Hedw.) Brid. - 11: exposed acidic rock

Rhabdoweisia fugax (Hedw.) Bruch et Schimp. - 3: exposed acidic rock

Rhizomnium punctatum (Hedw.) T. J. Kop. - 7: at a rivulet; 8: at the stream; 19: at the stream

Rhynchostegium murale (Hedw.) Schimp. - 11: at a rivulet and lime containing schist

Rhytidiadelphus triquetrus (Hedw.) Warnst. - 11: soil

Saelania glaucescens (Hedw.) Broth. - 11: lime containing schist

Schistidium apocarpum (Hedw.) Bruch et Schimp. - 3: shaded acidic rock; 7: schistose rock

Schistidium brunnescens Hedw. subsp. griseum (Nees et Hornsch.) H. H. Blom - 15: exposed limestone rock

Schistidium confertum (Funck) Bruch et Schimp. - 3: exposed acidic rock; 11: exposed acidic rock Schistidium crassipilum H. H. Blom - 2: schistose rock, 8: acidic rock at the stream; 11: lime containing schist and exposed acidic rock; 16, 19: shaded limestone rock; 17: limestone rock

Schistidium dupretii (Thér.) W. A. Weber - 11: at a rivulet

Schistidium papillosum Culm. - 11: exposed acidic rock 
Sciuro-hypnum populeum (Hedw.) Ignatov et Huttunen - 8: acidic rock

Scleropodium touretii (Brid.) L. F. Koch - 7: soil

Seligeria pusilla (Hedw.) Bruch et Schimp. - 11: lime containing schist; 16, 19: shaded limestone rock

Syntrichia montana Nees - 15: exposed limestone rock

Syntrichia ruralis (Hedw.) F. Weber et D. Mohr - 3: exposed acidic rock and bark of Fagus; 4: acidic conglomerate rock; 7: schistose rock; 11: exposed acidic rock; 13: acidic rock; 16, 19: shaded limestone rock

Syntrichia subpapillosissima (Bizot et R. B. Pierrot ex W. A. Kramer) M. T. Gallego et J. Guerra 11: exposed acidic rock

Taxiphyllum wissgrillii (Garov.) Wijk et Margad. - 19: shaded limestone rock

Thamnobryum alopecurum (Hedw.) Gangulee -19: at the stream

Timmia bavarica Hessl. - 16, 19: shaded limestone rock

Tortella fragilis (Hook. et Wilson) Limpr. - 11: exposed acidic rock

Tortella inclinata (R. Hedw.) Limpr. - 15: exposed limestone rock

Tortella tortuosa (Hedw.) Limpr. - 2: schistose rock; 3: exposed acidic rock; 11: lime containing schist; 13: acidic rock; 15: exposed limestone rock; 16: shaded limestone rock; 19: shaded limestone rock

Tortula atrovirens $(\mathrm{Sm}$.) Lindb. - 6: sandy loess wall

Tortula schimperi M. J. Cano, O. Werner et J. Guerra - 14: soil

Tortula subulata Hedw. - 1: acidic rock; 3: exposed acidic rock; 4, 7, 8, 14: soil; 11: lime containing schist; 12: sandy conglomerate loess wall; 16: shaded limestone rock; 19: shaded limestone rock and decaying wood

Trichostomum crispulum Bruch - 17: limestone rock

Weissia brachycarpa (Nees et Hornsch.) Jur. - 14: soil

Weissia condensa (Voit) Lindb. - 11: soil

Weissia controversa Hedw. - 11, 14: soil 